
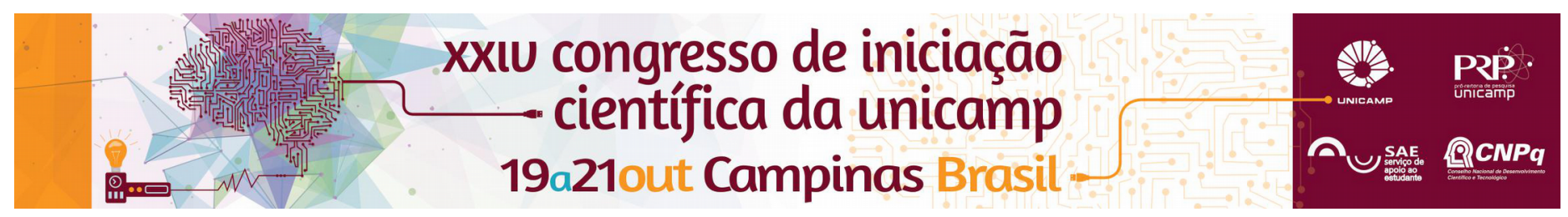

\title{
Introdução ao Documentário Queer: Contexto, Ideias e Filmes
}

\section{Caio Curtolo de Macedo*, Gilberto Alexandre Sobrinho}

\begin{abstract}
Resumo
A pesquisa pretende investigar sobre as origens do movimento de Documetário Queer, que tem início após a Revolta de Stonewall em 1969, marco para a formação de um movimento LGBT organizado, e que tem localidade nos Estados Unidos, principalmente nos centros urbanos de New York e Los Angeles. Através de pesquisa bibliográfica e filmográfica, será formado um panorama geral e introdutório, conceituando as principais temáticas presentes durante a primeira fase do movimento, da década de 1970 até o final da década de 1980.
\end{abstract}

\section{Palavras-chave:}

Documentário, Documentário Queer, Cinema Queer

\section{Introdução}

O movimento de Documentário Queer surge no início da década de 1970, nos Estados Unidos, após o episódio da Revolta de Stonewall, marco para a fundação de um movimento LGBT (lésbicas, gays, bissexuais e transgêneros) organizado mais combativo no país, que tinha como pauta principal o acesso aos direitos e privilégios que eram reservados aos heterossexuais até então. Os documentários vem como uma resposta à invisibilidade e difamação pública que as identidades não-heterossexuais sofriam no âmbito público do país, principalmente por parte de Hollywood e da TV aberta estadunidense. É possível separar o movimento de Documentário Queer em dois momentos: o primeiro tendo início na década de 1970 com duração até o final da década de 1980, objeto de estudo deste trabalho, e o segundo começando no início da década de 1990 e tendo duração até o tempo presente.

O objetivo deste trabalho é investigar as influências culturais que operavam nos Estados Unidos, principalmente cinematográficas, que levaram à formação do movimento e quais as características da sua primeira fase, e dar um panorama geral introdutório a ele, através de categorizações dos grandes temas que foram desenvolvidos durante as décadas de 1970 e 1980.

\section{Resultados e Discussão}

Através de pesquisas bibliográficas de textos sobre documentário e cinema queer, e pesquisa filmográfica que vai desde filmes dos anos de 1940 a documentários históricos produzidos da década de 1990 em diante, foi possível traçar um panorama cultural cinematográfico dos Estados Unidos que levou ao desenvolvimento de um Cinema Queer mais politicamente engajado nos anos de 1970, ao contrário do Underground Americano que começa no final da década de 1940 e se extende, com um hiato nos anos de 1950, até o final da década de 1960.

O Documentário Queer surge como uma resposta política à opinião pública negativa acerca de LGBT's, procurando estabelecer um senso comunitário através da partilha de experiências que todas as categorias identitárias não-heterossexuais partilhassem: a do sofrimento e rejeição. Para tanto é possível encontrar dividir os filmes produzidos no período em cinco grandes temáticas: comunitários, familiares, lésbicos, historiográficos e raciais, estando esta última apontando para o futuro do Cinema Queer, o Novo Cinema Queer em que as questões interseccionais se tornam mais urgentes, além da questão do desenvolvimento da AIDS dentro da comunidade de gays, bissexuais $\mathrm{e}$ transgêneros.

\section{Conclusão}

O Documentário Queer teve um valor político fundamental na consolidação da comunidade e movimento LGBT, pela sua potencialidade de trazer histórias pessoais a tona, dando peso político a elas e desenvolver um senso de cidadania em relação às questões de sexualidade e gênero. Eles circularam em cinemas e canais de televisão, influenciando as gerações futuras de cineastas que surgiria a partir dos anos de 1990, que formariam o movimento de Novo Cinema Queer, que alguns autores argumentam já ter se encerrado, mas que durou até tempos recentes dos anos 2000.

\section{Agradecimentos}

Gostaria de agradecer primeiramente ao meu orientador, o Prof. Dr. Gilberto Alexandre Sobrinho, ao PIBIC por viabilizar e financiar a produção deste trabalho, aos meus pais pela paciência e aos meus amigos pela ajuda. 